\title{
Dzieje skarbowości polskiej i jej prawa w pracach dr. hab. Jacka Matuszewskiego
}

$\mathrm{O}$ brażają się na mnie niektórzy przedstawiciele nauki prawa finansowego, gdy stwierdzam, że ich dzieła dotyczące współczesnego prawa finansowego nie mają większej wartości, ponieważ nie zawierają kontekstu historycznego. Na palcach jednej ręki można bowiem wyliczyć prace, a zwłaszcza podręczniki akademickie z dziedziny prawa finansowego, które zawierają skromny chociażby fragment poświęcony dziejom skarbowości lub jej instytucji. Opracowania te opierają się zresztą na wiedzy stworzonej przez historyków. Prawdą jest, że dogmatyk prawa, pozbawiony warsztatu badacza historii, nie jest w stanie samodzielnie zbadać zbyt wiele dziejów skarbowości. Lepiej jest zatem, gdy korzysta z wiedzy historyków. Nie powinien jednak czynić tego w sposób bezkrytyczny. Historycy mają bowiem tendencję do detalicznego ujmowania samych faktów. Tymczasem powinni być również otwarci na ich ocenę w świetle pojęć i konstrukcji występujących w dogmatyce prawa. To zaś wymaga od nich minimalnej chociażby znajomości prawa obowiązującego.

Osobiste przyjaźnie, jakie łączą mnie od dawna z historykami prawa i romanistami sprawiaja, że co prawda wśród nich czuję się maleńki, ale w gronie moich kolegów dogmatyków prawa mam już poczucie wyższości. Wiedza historyczna mocno mnie wzbogaca. Pozwala zrozumieć więcej i lepiej oraz łatwiej oceniać teraźniejszość i projektować przyszłość. Nie muszę, tak jak czynią to inni, wróżyć z fusów, ani też kompromitować się opowiadaniem legend, nieznanych nawet w mitologii. Wiele satysfakcji przyniosły mi więc własne badania dziejów administracji skarbowej we Francji oraz skarbowości polskiej okresu międzywojennego i PRL. Kiedyś okazało się jednak, że poznanie skarbowości polskiej wymaga znacznie większej wiedzy. Uzmysłowił mi to młodszy kolega z łódzkiego Wydziału Prawa, dr Jacek Matuszewski. Przygotowując swoją rozprawę habilitacyjną zapytał mnie, co sądzę na temat znaczenia przywileju koszyckiego. Odpowiedziałem co wiedziałem zaznaczając, że denerwuje mnie to, 
że moi czescy i słowaccy koledzy „zawłaszczyli” ten przywilej dla siebie i piszą o nim w podręcznikach prawa finansowego jak o akcie, od którego wywodzi się historia budżetu państwa na ziemiach Czech i Słowacji! Młody adiunkt uspokoił mnie o tyle, że odmówił im racji, ale jednocześnie stwierdził, że ja również nie mam o tym zbyt dużego pojęcia! Poznanie prawdy stało się możliwe dopiero po zapoznaniu się z monografią Jacka S. Matuszewskiego ${ }^{1}$.

Rozprawa ta zasługuje na uwagę nie tylko ze względu na jej problematykę i przeprowadzone dowody oraz wnioski końcowe. Uwagę zwraca metodologia badawcza autora. W pierwszej kolejności odniósł się on do oceny stanu dotychczasowych badań i ustaleń historyków na temat skarbowości polskiej w XIV w. Autor nie podzielił ich zasadności. Zwrócił też uwagę na związki przywileju koszyckiego z wcześniejszymi przywilejami (np. z przywilejem budzińskim). Poddał również ocenie stan podatków w okresie poprzedzającym ustanowienie wspomnianych przywilejów. Rozprawa zawiera zarówno krytykę dotychczasowych ustaleń historyków, jak i wadliwych ocen zawartych w przekazach kronikarskich. W tym momencie ukazał się prawdziwy talent badawczy Jacka Matuszewskiego i jego zadziorny charakter. Pokazał bowiem, że szanuje wszystkich, ale zgadza się z nielicznymi i ma swoje zdanie na różne tematy! Tak mu to już zresztą zostało. Jedni go za to szanują, inni nienawidzą. Samo życie.

Jacek Matuszewski wszechstronnie zbadał okoliczności powstania przywileju koszyckiego i jego znaczenie. Dostrzegł więc wagę I zjazdu koszyckiego z 1373 r., nieobojętnego również dla miasta Poznania i mieszczan wielkopolskich, czyli ziemi, na której on sam się urodził i gdzie odebrał szkolną edukację. Trafnie ocenił skutki polityczne i finansowe przywileju, w tym zmiany w obciążeniu podatkowym, zwłaszcza w dochodach feudałów i duchowieństwa. Jacek Matuszewski jednoznacznie wykazał, że przywilej koszycki był gestem monarchy wobec szlachty, udzielonym za cenę pozostania przy władzy dynastii Andegawenów. Autor ocenił ten fakt pozytywnie uznając, że przywilej tworzył nową sytuację w systemie podatkowym, ponieważ miejsce podatków nadzwyczajnych zajął stały podatek łanowy. Uznał przy tym, że zapewniało to poważne i stałe wpływy do skarbu państwa, a przez to doszło do stworzenia przez Ludwika Węgierskiego bardzo racjonalnego systemu podatkowego.

Ocen tych nie podzielam bez zastrzeżeń. Jak zresztą przyznaje sam J. Matuszewski już „w połowie XV w. system ten przestał odpowiadać

${ }^{1}$ J. S. Matuszewski, Przywileje i polityka podatkowa Ludwika Wegierskiego w Polsce, AUL, 1983, ss. 252. 
potrzebom państwa i był powodem narastającego kryzysu skarbu Rzeczypospolitej szlacheckiej". Jest jeszcze inny powód, dla którego należy nieco inaczej oceniać znaczenie przywileju koszyckiego. Król zrzekł się w nim arbitralnego prawa nakładania jednorazowych (nadzwyczajnych) podatków. Fakt ten należy oceniać i mierzyć w kategoriach zbliżonych do gestu angielskiego króla zawartego w Wielkiej Karcie Wolności z 1215 r. i wykonanego na rzecz ówczesnych stanów. Jednocześnie silniejszego podkreślenia wymaga jednak to, że władza od dawna traktowała podatki jak „kiełbasę wyborczą”. To się przyjęło w sposób powszechny i chyba na stałe, jeśli rzecz oceniać również $\mathrm{w}$ świetle współczesnych kampanii wyborczych, w których podatki odgrywają ważną kartę przetargową.

Należy żałować, że rozprawa habilitacyjna Jacka S. Matuszewskiego nie została wydana $w$ języku obcym ${ }^{2}$. Nie jest przez to szczególnie znana w Czechach i na Słowacji. To pozwala tamtejszym historykom i dogmatykom prawa pozostawać nadal w przekonaniu, że ... historia skarbowości rozpoczęła się na ich ziemiach, chociaż Ludwik Węgierski był nie tylko ich królem. Władze uczelni wyrządziły przy tym Jackowi Matuszewskiemu wielką krzywdę uniemożliwiając mu wyjazdy zagraniczne, dzięki którym mógłby on rozpowszechnić znajomość swojego dzieła wśród innych uczonych. Tak bywało dawniej i niewiele zmieniło się niestety po 4 czerwca 1989 r. w odniesieniu do tych, którzy autentycznie mają coś ważnego do powiedzenia.

Jacek Matuszewski jest autorem licznych prac naukowych. Interesowały go różne tematy. Badał je i opisywał, nie stroniąc przy tym od patrzenia na pewne kwestie historyczne $\mathrm{w}$ jednoczesnym nawiązaniu do współczesnych wydarzeń. Jest to zaletą nielicznych tylko historyków. Jacek Matuszewski stara się tymczasem tkwić ze swoją bogatą wiedzą historyczną w teraźniejszości. Jego zasługą jest również to, że nie stroni od dzielenia się z nami swoimi ustaleniami w zakresie metodologii badania skarbowości polskiej. Dał temu wyraz w inicjatywie dotyczącej poświęcenia skarbowości polskiej odrębnego tomu „Studiów z Dziejów Państwa i Prawa Polskiego" ${ }^{\prime \prime}$. Wskazał wówczas na znaczenie badań nad dziejami skarbowości oraz na trudności wiążące się z ustaleniem początku dziejów polskiej skarbowości. Na tym tle odniósł się do finansów okresu Jagiellonów, chociaż prac na ten temat nie brakuje.

${ }^{2}$ Najważniejsze fragmenty rozprawy zostały opublikowane w skrócie w formie artykułu napisanego w języku francuskim zob.: La signification des privileges fiscaux de Louis de Hongrie en Pologne, Acta Pol. Hist., 1985, t. LI [wyd. 1986], s. 33-50.

${ }^{3}$ Zob. J. S. Matuszewski, Uwagi wprowadzajace - początki skarbowości publicznej, „Studia z Dziejów Państwa i Prawa Polskiego" 2003, t. VIII, s. 9-18. 
Zastanawiam się nad tym, kto z premierów i ministrów finansów współczesnych rządów polskich, tak mocno palących się do sprawowania tej funkcji, wiedział o tym, o czym już dawno pisał Jacek Matuszewski twierdząc, że:

- finanse to istotny czynnik decydujący o rozwoju i funkcjonowaniu struktur państwowych i społecznych,

- niewydolny system finansów publicznych - to powszechnie przyjmowana, podstawowa i bezpośrednia przyczyna upadku Rzeczypospolitej,

- słabość finansowa II Rzeczypospolitej miała ostatecznie przesądzić o wyniku kampanii wrześniowej,

- finanse to w istocie warunek wszelkiej działalności państwa,

- bez dobrej znajomości tej sfery stosunków publicznych badania nad państwem nie mogą przynieść satysfakcjonujących wyników.

Jacek Matuszewski uznał, że dzieje polskiej skarbowości, mimo wielokrotnego i szczegółowego jej analizowania, nie doczekały się monograficznego i syntetycznego opracowania. Nie sądzę, aby stwierdzenie to podobało się autorom licznych prac poświęconych tej problematyce. Nie wiem, czy J. Matuszewski ma rację i czy opracowanie całości tego tematu jest możliwe, skoro historycy uwielbiają opis detali, zbędnych w gruncie rzeczy z punktu widzenia oceny instytucji prawnych. Być może jednak środowisko historyków prawa mogłoby zdobyć się na zbiorowy wysiłek i opracować pełne dzieje skarbowości polskiej i prawa skarbowego w kil$\mathrm{ku}$ tomach?

Jacek Matuszewski wskazał na niebezpieczeństwa grożące w badaniach nad skarbowością polską. To jest ważne, bo zagrożenia te tkwią zarówno w wiarygodności źródeł wiedzy o skarbowości, jak i w używaniu przez historyków niewłaściwej terminologii z zakresu skarbowości. Jacek Matuszewski zwrócił uwagę na potrzebę posługiwania się pewnymi danymi liczbowymi przy ocenie określonych zjawisk finansowych. $\mathrm{Z}$ tych powodów zakwestionował wiarygodność ustaleń zawartych w niektórych pracach historycznych dotyczących skarbowości polskiej. Nie jestem co prawda pewien, czy zachęcił tym do jej dalszego badania, zwłaszcza młodych adeptów historii prawa.

Jedną z ważniejszych prac naukowych J. Matuszewskiego poświęconych skarbowości jest kapitalna rozprawka na temat słabości polskiej skarbowości w okresie I Rzeczypospolitej ${ }^{4}$. Autor podzielił przede

${ }^{4} \mathrm{~J}$. S. Matuszewski, O szlacheckiej schizofrenii, czyli o trudnych początkach polskiego prawa finansowego, [w:] Nauka finansów publicznych i prawa finansowego w Polsce. Dorobek i kierunki rozwoju. Księga jubileuszowa Profesor Alicji Pomorskiej, red. J. Głuchowski, C. Kosikowski, J. Szołno-Koguc, Lublin 2008, s. 31-45. 
wszystkim pogląd Władysława Pałuckiego ${ }^{5}$ o tym, że „Sprawy skarbowe Rzeczypospolitej [...] należą do tych zagadnień, które leżały u podstaw koniecznych, lecz niedokonanych reform całego ustroju państwowego". W przeciwieństwie do większości innych historyków skarbowości J. Matuszewski potrafił uogólnić fakty historyczne i wyciągnąć z nich wnioski przydatne w kształtowaniu naszej współczesności. Wskazał zatem na to, że w dziejach skarbowości wyłoniły się dwa modelowe rozwiązania. Jedno opiera skarbowość na rodowej podstawie materialnej władcy i uwalnia go od woli poddanych w zakresie ich obciążania. Natomiast drugi model opiera skarbowość na finansowaniu niezbędnych zadań państwa zależnie od każdorazowej zgody poddanych na sięgnięcie do ich kieszeni. J. Matuszewski, mimo iż krytycznie odniósł się do niektórych wcześniejszych prac poświęconych skarbowości polskiej (np. w kwestiach pojęcia skarbu i jego podziału na prywatny i publiczny), to jednocześnie przyznał, że w Polsce szlacheckiej nie udało się zastosować z powodzeniem żadnego $\mathrm{z}$ tych modeli. Władcy byli zbyt słabo wyposażeni $\mathrm{w}$ dobra rodowe, a często będąc nie-Polakami nie mieli też ochoty finansować zadań państwa polskiego z własnych domen i regaliów. Przeważał więc drugi model organizacji skarbowości. Towarzyszyły mu liczne próby reformatorskie, ale ich wspólną przyczyną i cechą było to, że podejmowano je wyłącznie w celu wyzwolenia się szlachty i duchowieństwa od istniejących obciążeń daninowych i poszerzenia kręgu przywilejów podatkowych tych grup. To nie były więc reformy proponowane lub przeprowadzane z myślą o poprawie skarbowości polskiej!

J. Matuszewski uznał, że „podstawowym i w zasadzie jedynym powodem niereformowalności skarbowości szlacheckiej był brak koncepcji, która gwarantowałaby jednocześnie; a) ochronę szlachty przed koniecznością ponoszenia ciężarów na rzecz państwa, b) możliwość przejmowania przez szlachtę dochodów, jakie płynęły lub płynąć mogły z zasobów publicznych, c) utrzymanie zależności władcy od stanu szlacheckiego". Szkoda, że prawda ta nie dociera do współczesnych funkcjonariuszy państwowych (np. parlamentarzystów, premierów i członków rządu). Rozśmieszać nas mogą jedynie głoszone obecnie przez polityków „koncepcje" podatkowe polegające na proponowaniu jedynie zmniejszenia lub zwiększenia stawki podatkowej $\mathrm{w}$ wybranym podatku lub obciążenia podatkami tych, którzy ich jeszcze nie płacą. Wielu proponuje specjalne opodatkowanie bogatych, zapominając o tym, że teraz mamy ustrój kapitalistyczny, którego podstawą jest kapitał. Nikt z tych „reformatorów”

${ }^{5}$ W. Pałucki, Drogi i bezdroża skarbowości polskiej XVI i pierwszej połowy XVII wieku. Nervus belli, Wrocław 1974. 
nie ma zresztą bladego pojęcia o tym, czym jest system podatkowy i jakie powinno być prawo podatkowe, drugie, po prawie karnym, prawo dyscyplinujące życie zawodowe i osobiste obywateli.

Ustalenia dokonane przez J. Matuszewskiego w omawianej wyżej pracy mają kapitalne znaczenie dla wielu kwestii. Sądzę, że w sposób przez siebie niezamierzony wskazał on na genezę ustroju socjalistycznego, w którym państwo (władca) oparło finansowanie swoich zadań publicznych niemal wyłącznie na dochodach z własności państwowej, do podatków sięgając $w$ niewielkim stopniu i jedynie w celach interwencyjnych (likwidacja lub ograniczenie tzw. nieuspołecznionego sektora gospodarczego). Obywatele nie płacili podatków, a państwo finansowało niemalże wszystkie ich potrzeby. System jednak padł, bo 4 czerwca $1989 \mathrm{r}$. dalece nie wszyscy byli z niego zadowoleni. Dzisiaj ci sami... wspominają dobre, stare, czasy, a młodzi powtarzają jak papugi, że wszystkiemu winna jest komuna, w tym też temu, że brak jest miejsc pracy lub zatrudnianiu na umowach śmieciowych!

J. Matuszewski zwrócił naszą uwagę na fakt, że długo nie było w historii państwa rozdzielenia władzy legislacyjnej, wykonawczej i sądowniczej. Nie było zatem potrzeby tworzenia odrębnych norm dzielących władzę w dziedzinie skarbowości. Początki polskiego prawa skarbowego wiązały się przede wszystkim z wydawaniem przez władcę aktów ustanawiających przywileje podatkowe. Skoro jednak nie było stałych podatków, to nie było też potrzeby ustanawiania prawa podatkowego. Pobór i egzekucja danin należała do urzędników skarbowych bądź też była przedmiotem dzierżawy władztwa daninowego. Nie powstał jeszcze budżet państwa, a więc nie stanowiono też norm dotyczących jego sporządzania, wykonywania i kontroli.

Udało mi się przekonać Jacka Matuszewskiego do tego, aby częściej zajmował się badaniem polskiej skarbowości, bo jest to konieczne, a jego ustalenia są wręcz bezcenne dla nauki prawa finansowego. $W$ ten sposób doszło do tego, że Profesor zaczął pojawiać się na konferencjach naukowych organizowanych przez przedstawicieli nauki prawa finansowego oraz dał się namówić na udział w przygotowywaniu fragmentów podręczników akademickich z zakresu finansów publicznych i prawa finansowego, a potem także na udział w tworzeniu wielotomowego Systemu prawa finansowego.

Rozpoczęło się skromnie, od dwóch opracowań, powstałych zresztą we współautorstwie. Pierwsze dotyczyło genezy i pojęcia oraz ewolucji zakresu prawa finansowego ${ }^{6}$. Jego najważniejsze ustalenia odnoszą się

${ }^{6}$ Zob. C. Kosikowski, J. S. Matuszewski, Geneza i pojęcie oraz erwolucja zakresu prawa finansowego, [w:] Finanse publiczne i prawo finansowe, red. C. Kosikowski i E. Ruśkowski, Warszawa 2006, s. 46-58. 
do: 1) wskazania na genezę finansów publicznych, 2) wyróżnienia w rozwoju finansów publicznych na ziemiach polskich trzech różnorodnych etapów, 3) wskazania na powstanie prawa skarbowego i na jego rozwój oraz emancypację. Takich ustaleń nie dokonał nikt przed nami. Przyjęliśmy bowiem, że "o finansach publicznych możemy mówić z chwila gdy pojawiają się normy regulujące zawłaszczanie przez państwo $\mathrm{w}$ interesie społecznym przychodów prywatnych, a następnie powrotnego przekazywania uzyskanych $\mathrm{w}$ ten sposób środków w ręce najczęściej innych prywatnych osób".

Określając etapy rozwojowe finansów publicznych wyraźnie wyróżniliśmy okres przełomu XIII i XIV wieku, w którym przy prymitywnej wręcz grabieży poddanych, dominowały wszelkiego rodzaju świadczenia na rzecz władzy o charakterze naturalnym (produkty rolne, rzemieślnicze, robocizna), mimo że znana była już przecież instytucja pieniądza. W drugim etapie rozwojowym panowała wolność podatkowa stanów społecznych, a państwo realizowało swe zadania dzięki środkom uzyskiwanym z domeny królewskiej, wspomaganym co najwyżej doraźnymi podatkami nadzwyczajnymi (np. na cele wojskowe). Dopiero od połowy wieku XVIII można mówić o finansach publicznych odgrywających nie tylko rolę fiskalną, lecz także interwencyjną (np. wspieranie rodzimej gospodarki, rozwój miast, rozbudowa infrastruktury komunikacyjnej).

Powstania prawa skarbowego nie wiążemy $\mathrm{z}$ faktem wydawania przez władcę przepisów instrukcyjnych adresowanych do urzędników królewskich zajmujących się pobieraniem danin publicznych. Uważamy natomiast, że o prawie skarbowym można mówić dopiero wtedy, gdy relacje państwo - poddani zamieniły się w relacje państwo - obywatele, a więc gdy doszło do upodmiotowienia prawnego społeczeństwa. Rozwój polskiego prawa skarbowego postrzegamy na tle wydarzeń zachodzących na ogół wcześniej w innych państwach. Zasługą Jacka Matuszewskiego jest m.in. ustalenie, że o powstaniu skarbu publicznego zadecydowały różne wydarzenia i to zachodzące na przestrzeni wielu lat, a nie tylko pojedyncze fakty (np. podział urzędu podskarbiego na koronny i nadworny), jak i zwrócenie uwagi na zmiany zachodzące wśród źródeł prawa skarbowego (od aktów królewskich do aktów parlamentarnych).

W innym opracowaniu J. Matuszewski przeprowadził wraz z Janem Głuchowskim analizę genezy dochodów budżetowych ${ }^{7}$. Zajął się daninami publicznymi, które wprowadzano na przestrzeni wieków w Polsce. Dzięki temu czytelnicy podręcznika mogą wreszcie dowiedzieć się tego,

${ }^{7}$ J. Głuchowski, J. S. Matuszewski, Geneza dochodów budżetowych, [w:] Finanse publiczne..., s. 478-485. 
co każdy wykształcony człowiek powinien wiedzieć na ten temat, nie wykluczając z tego grona polityków. J. Matuszewski opisuje czasy, w których władca sam pokrywał wydatki związane ze sprawowaniem władzy oraz z obronnością państwa. Potem zaś wskazuje na czasy, w których szlachta i duchowieństwo walczą z królem o przywileje podatkowe. Szkoda, że ewolucji takiej nie ukazano również $\mathrm{w}$ odniesieniu do okresu Polski porozbiorowej, bo był to czas obowiązywania różnych systemów podatkowych i stopniowego dochodzenia do własnych rozwiązań prawnych.

W innym podręczniku akademickim znalazły się nie tylko dwa omówione wyżej opracowania z udziałem J. Matuszewskiego, lecz także dwa nowe. Pierwsze z nich poświęcono genezie i ewolucji administracji finansów publicznych ${ }^{8}$. Podczas gdy ja wskazywałem na rozwiązania zastosowane $w$ innych państwach, to J. Matuszewski opisał i ocenił przede wszystkim historię polskiej administracji skarbowej. Wywiódł ją od instytucji zarządu prywatnym skarbem książęcym. Następnie zaś wskazywał na przejęcie administracji przez dzierżawców domen lub zastawników, przy jednoczesnym utrzymywaniu urzędu podskarbiego. Wyjaśnił też władztwo skarbowe sejmików, trybunałów skarbowych i komisji Skarbowej, a potem urzędu skarbnika i urzędu mincerza, kasztelanów, żupanów i komesów itd. Zrozumienie zadań tych urzędów pozwala lepiej pojać, dlaczego z czasem musiało dojść do powstania urzędu ministra skarbu oraz do pojawienia się odrębnej administracji samorządowej, a także instytucji kontrolnych w dziedzinie finansów publicznych. J. Matuszewski dostarczył czytelnikom podręcznika takiej właśnie wiedzy. Warto o tym pamiętać.

W omawianym podręczniku znalazło się też samodzielne opracowanie J. Matuszewskiego poświęcone genezie i ewolucji wydatków publicznych ${ }^{9}$. Nie znajdziecie tego opisu w żadnym innym podręczniku akademickim $z$ dziedziny finansów i prawa finansowego. Znaczenie tego opracowania jest kapitalne dzięki temu, że J. Matuszewski słusznie zakwestionował dominujące przekonanie o prymacie dochodów nad wydatkami publicznymi. Autor wskazuje bowiem, że jest dokładnie odwrotnie, bo dochodów publicznych nie gromadzono, gdy nie było wydatków publicznych. Dopiero powstanie skarbu rawskiego (kwarcianego) świadczy o tym, że pojawienie się stałych wydatków wymagało ustalenia stałych dochodów. J. Matuszewski ocenia, że „W przypadku systemu finansów

${ }^{8}$ C. Kosikowski, J. S. Matuszewski, Pojęcie, geneza i ewolucja oraz problemy administracji finansów publicznych, [w:] Finanse publiczne i prawo finansowe, red. C. Kosikowski, E. Ruśkowski, Warszawa 2008, s. 133-143.

9 J. S. Matuszewski, Geneza i ewolucja wydatków publicznych, [w:] Finanse publiczne..., Warszawa 2008, s. 680-686. 
publicznych państwa szlacheckiego cel, który związany był z kształtującym się $\mathrm{w}$ drodze praktyki systemem określania zadań skarbu przez wskazywanie wydatków niezbędnych do zaspokojenia, nie zawsze był zadaniem nadrzędnym". To stało się zresztą przyczyną jego niewydolności. Zdaniem J. Matuszewskiego wydatki publiczne niezmiennie miały charakter polityczny. Być może dlatego ustalaniu ich struktury i wysokości towarzyszyła arbitralność władzy publicznej w wyborze politycznych celów przeznaczenia środków publicznych.

Jacek Matuszewski przyjął zaproszenie do udziału w pracach nad czterotomowym Systemem prawa finansowego. Opublikował tam we współpracy z innymi autorami trzy opracowania. Dwa z nich stanowia poprawioną i rozszerzoną wersję opracowań zamieszczonych wcześniej w podręcznikach z finansów i prawa finansowego ${ }^{10}$. Na ich walory wskazywałem wyżej. Dlatego nie mogło ich zabraknąć w Systemie prawa finansowego.

Nową wersję otrzymało też trzecie opracowanie, które powstało $\mathrm{z}$ udziałem innych autorów, w tym dwóch historyków prawa ${ }^{11}$. Jest to pierwsze w naszej literaturze całościowe spojrzenie na dzieje systemu zarządzania finansami publicznymi w okresie obejmującym czasy od starożytności do teraźniejszości. W tym zestawie Jackowi Matuszewskiemu przypadło w udziale opracowanie tematu dotyczącego okresu do wieku XVIII (s. 87-94). Autor przypomniał przyczyny, dla których bardzo długo nie dochodziło do wykształcenia się zwartego systemu administracji skarbowej. Wielość skarbów oznaczała bowiem również konieczność odrębnego zarządzania nimi ze strony różnych urzędów. Feudalny, prywatnoprawny charakter administracji skarbowej państwa szlacheckiego zachowała się aż do XVIII stulecia, kiedy podjęte zostały próby tworzenia nowożytnej administracji. Piszą o nich już dwaj inni współautorzy opracowania.

Jacek Matuszewski pochodzi z rodzinny profesorskiej. Jest zatem zrozumiałe, że z należnym szacunkiem i estymą odnosi się do innych profesorów. Nawet wtedy, gdy się z nimi nie zgadza ${ }^{12}$. Gdy podjąłem de-

${ }^{10}$ C. Kosikowski, J. S. Matuszewski, Geneza i ewolucja oraz stan obecny i przewidywana przyszłość prawa finansowego, [w:] System prawa finansowego, t. I, Teoria i nauka prawa finansowego, red. C. Kosikowski, Warszawa 2010, s. 15-34; C. Kosikowski, J. S. Matuszewski, Geneza i ewolucja oraz funkcje podatków, [w:] System prawa finansowego, t. II, Prawo daninowe, red. L. Etel, Warszawa 2010, s. 39-61.

${ }^{11}$ C. Kosikowski, J. S. Matuszewski, W. Witkowski, Przeksztatcenia w zakresie zarzadzania finansami publicznymi i administracji skarbowej jako element ustrojowego prawa finansowego, [w:] System prawa finansowego..., t. I, s. 83-174.

${ }^{12}$ Zob. np. J. S. Matuszewski, T. Szulc, Opodatkowanie i polityka zastawu miast królewskich w Polsce za Jagiellonów. Uwagi w związku z książk Michaela Ludwiga, CPH, 1989, t. XLI, z. 2, s. 175-192. 
cyzję o przygotowaniu księgi dedykowanej mojemu Mistrzowi, poprosiłem o pomoc J. Matuszewskiego. Nie zawiodłem się, bo ten opracował biogram Profesora Jerzego T. Lubowickiego oraz rzetelnie zestawił bibliografię jego prac ${ }^{13}$. Jeszcze raz za to dziękuję.

Nie wszyscy dobrze znają Jacka Matuszewskiego, ale sądzę, że tylko nieliczni nie dostrzegli w nim olbrzymich pokładów dowcipu i anegdot. Wielu pamięta jego ulubionego owczarka Legata. Miłość do psów i dobrego dowcipu zbliżyła nas na tyle, że w przypływie dobrego nastroju wywołanego kuflami piwa spożywanego w towarzystwie naszych psów postanowiliśmy poświęcić im naukową rozprawę ${ }^{14}$. Znaczną jej część opracował J. Matuszewski. On bowiem podszedł do tematu poważnie. Za konieczne uznał przedstawienie pozycji psa jako zwierzęcia oraz jego relacji z człowiekiem i wobec prawa. Odrębnie wskazał na problem psów kampfhundów. Przede wszystkim jednak przygotował dokumentację opisu ewolucji podatku od psów na całym świecie i to zarówno w ujęciu historycznym, jak i w świetle danych statystycznych. Mnie pozostała już tylko kpina z regulacji polskich i praktyki ich stosowania oraz zaproponowanie rozwiązania problemu w przyszłości. J. Matuszewski nie byłby soba, gdyby nie wzbogacił monografii zestawieniami wyjaśnień typu: „Dlaczego lepiej mieć psa, niż żonę?" lub „Dlaczego pies jest lepszy niż mąż?”

Książka miała dwa wydania, przy czym drugi nakład w całości wykupił ówczesny minister kultury i dziedzictwa narodowego, ponieważ uznał, że lepszego prezentu niż ta książka nie kupi nigdzie! Posłowi R. Kaliszowi musieliśmy przekazać drugi egzemplarz książki, bo pierwszy pożyczył on nieopatrznie Prezydentowi A. Kwaśniewskiemu. Długo cieszyliśmy się tym, że sprawiliśmy wiele radości ludziom. Natomiast niektórzy nasi koledzy uznali, że nasza monografia jest przykładem tego, jak każdy temat można potraktować naukowo. Trzeba jednak opracować go w zgodzie z metodologią prac naukowych oraz w sposób przystępny, a także zachęcający do lektury (dowcipy, zdjęcia psów z naszymi komentarzami).

W oczekiwaniu na dalsze prace Profesora Jacka Matuszewskiego z dziedziny historii skarbowości i prawa skarbowego nie ośmielam się oceniać jego dotychczasowego dorobku w tym zakresie. Jest on bezcenny i dlatego powinien być dalej powiększany.

${ }^{13}$ Zob. J. S. Matuszewski, Jerzy Telesfor Lubowicki - życie i twórczość... oraz J. Matuszewski, Bibliografia prac Profesora Jerzego Lubowickiego, [w:] Prawo skarbowe i prawo finansowe. Szkoły i uczniowie. Księga dedykowana pamięci Profesora Jerzego Lubowickiego, red. C. Kosikowski, Białystok 2013, s. 15-26.

${ }^{14}$ C. Kosikowski, J. S. Matuszewski, Opodatkowanie posiadania psów, czyli płacz ze śmiechu wokót budy. Studium obyczajowo-prawne, Warszawa 2002, ss. 318. 


\section{Bibliografia}

Kosikowski C., Matuszewski J. S., Geneza i ewolucja oraz funkcje podatków, [w:] System prawa finansowego, t. II, Prawo daninowe, red. L. Etel, Warszawa 2010.

Kosikowski C., Matuszewski J. S., Geneza i ewolucja oraz stan obecny i przewidywana przyszłość prawa finansowego, [w:] System prawa finansowego, t. I, Teoria i nauka prawa finansowego, red. C. Kosikowski, Warszawa 2010.

Kosikowski C., Matuszewski J. S., Geneza i pojęcie oraz ewolucja zakresu prawa finansowego, [w:] Finanse publiczne i prawo finansowe, red. C. Kosikowski i E. Ruśkowski, Warszawa 2006.

Kosikowski C., Matuszewski J. S., Opodatkowanie posiadania psów, czyli płacz ze śmiechu wokół budy. Studium obyczajowo-prawne, Warszawa 2002.

Kosikowski C., Matuszewski J. S., Pojęcie, geneza i ewolucja oraz problemy administracji finansów publicznych, [w:] Finanse publiczne i prawo finansowe, red. C. Kosikowski, E. Ruśkowski, Warszawa 2008.

Kosikowski C., Matuszewski J. S., W. Witkowski, Przeksztatcenia w zakresie zarzadzania finansami publicznymi $i$ administracji skarbowej jako element ustrojowego prawa finansowego, [w:] System prawa finansowego, t. I, Warszawa 2010.

Matuszewski J., Bibliografia prac Profesora Jerzego Lubowickiego, [w:] Prawo skarbowe i prawo finansowe. Szkoły i uczniowie. Ksiegga dedykowana pamięci Profesora Jerzego Lubowickiego, red. C. Kosikowski, Białystok 2013.

Matuszewski J. S., Jerzy Telesfor Lubowicki - życie i twórczość, [w:] Prawo skarbowe i prawo finansowe. Szkoty i uczniowie. Księga dedykowana pamięci Profesora Jerzego Lubowickiego, red. C. Kosikowski, Białystok 2013.

Matuszewski J. S., O szlacheckiej schizofrenii, czyli o trudnych poczatkach polskiego prawa finansowego, [w:] Nauka finansów publicznych i prawa finansowego w Polsce. Dorobek i kierunki rozwoju. Księga jubileuszowa Profesor Alicji Pomorskiej, red. J. Głuchowski, C. Kosikowski, J. Szołno-Koguc, Lublin 2008.

Matuszewski J. S., Przywileje i polityka podatkowa Ludwika Weegierskiego w Polsce, AUL, [Łódź] 1983.

Matuszewski J. S., Uwagi wprowadzajace - początki skarbowości publicznej, „Studia z Dziejów Państwa i Prawa Polskiego" 2003, t. VIII.

Matuszewski J. S., Szulc T., Opodatkowanie i polityka zastawu miast królewskich w Polsce za Jagiellonów. Uwagi w związu z książa Michaela Ludwiga, CPH, 1989, t. XLI, z. 2.

Pałucki W., Drogi i bezdroża skarbowości polskiej XVI i pierwszej połowy XVII wieku. Nerous belli, Wrocław 1974. 